Doi: HTTPS://DOI.ORG/10.23910/2/2020.0366

\title{
Impact of High Temperature Stress in Rice
}

\author{
E. Umarani ${ }^{1 *}$, V. Hemalatha ${ }^{2}$, A. Saritha ${ }^{1}$ and A. V. Ramanjaneyulu ${ }^{1}$
}

\author{
${ }^{1}$ Agricultural Research Station, Professor Jayashankar Telangana State Agricultural University, Tornala, Siddipet, \\ Telengana, (502 114), India \\ ${ }^{2}$ College of Agriculture, Professor Jayashankar Telangana State Agricultural University, Rajendranagar, Hyderabad, \\ Telengana (500 030), India
}

\section{Corresponding Author}

E. Umarani

e-mail: umaranierrabelli@gmail.com
Article History

Article ID: IJEP0366

Received in $16^{\text {th }}$ March, 2020

Received in revised form $28^{\text {th }}$ April, 2020

Accepted in final form $06^{\text {th }}$ June, 2020

\begin{abstract}
Global warming has become a big concern in the world and it has been continuously increasing in recent decades due to the greenhouse effect. The increase in temperature has been striking and it can cause irreversible damage to plant growth and development. Though rice originates from the tropics, high temperatures of more than $35^{\circ} \mathrm{C}$ during the reproductive stages reduces rice production, especially when the rice plant flowers when the high temperature occurs because it causes low seed setting and low yield. It was found that rice grain yield declined by $10 \%$ for each $1{ }^{\circ} \mathrm{C}$ increase in growing-season minimum temperature. Early-morning flowering is an important criteria in rice which escapes plant from high temperatures during peak period. It was found that Oryza glaberrima, a wild species of rice, is a useful genetic source since it has a habit of early-morning flowering and high transpiration with sufficient water, both of which are convenient traits for avoiding heat stress.
\end{abstract}

Keywords: Global warming, growth and development, high temperature, rice and yield

\section{Introduction}

Nowadays, Global warming has become a big concern in the World; it has been continuously increasing in recent decades due to the greenhouse effect (Crowley, 2000). Global climate model projections concluded that global surface temperature is likely to further rise by $1.1{ }^{\circ} \mathrm{C}$ to $2.9{ }^{\circ} \mathrm{C}$ for their lowest emissions scenarios and by $2.4{ }^{\circ} \mathrm{C}$ to $6.4{ }^{\circ} \mathrm{C}$ for their highest emissions scenarios (Meehl et al., 2007). The increase in temperature has been striking and can cause irreversible damage to plant growth and development (Wahid et al., 2007). High temperature stress is one of the major abiotic limiting factors in the rice production worldwide. Peng et al. (2003) found that rice grain yield declined by $10 \%$ for each $1^{\circ} \mathrm{C}$ increase in growing-season minimum temperature.

At present, most of the rice growing regions where current temperatures are already close to optimum for rice production. Therefore, any further increases in mean temperatures or of short episodes of high temperatures during sensitive stages may be supra-optimal and reduce grain yield. Yields of rice have been estimated to be reduced by $41 \%$ by the end of the $21^{\text {st }}$ Century (Ceccarelli et al., 2010). There is sufficient evidence that increasing night-time temperature has been the main cause of increases in global mean temperatures since the middle of the $20^{\text {th }}$ Century and is thus the main factor contributing to the yield decrease. Hence, heat stress poses a serious threat to sustaining rice production in the most productive regions of tropical Asia. Thus, heat tolerance has to be integrated into future rice breeding programs.

\section{High Temperature in Relation to Growth and Development of the Rice}

Temperature, along with photoperiod, is the main driving force for crop development. The optimum temperature for the normal development of rice ranges from $27^{\circ} \mathrm{C}$ to $32{ }^{\circ} \mathrm{C}$ (Yin et al. 1996). High temperature affects almost all the growth stages of rice. The developmental stage at which the plant is exposed to heat stress determines the severity of the possible damage to the crop (Wahid et al., 2007). However, flowering (anthesis and fertilization) and to a lesser extent the preceding stage booting (microsporogenesis) are considered to be the stages of development most susceptible to temperature in rice (Farrell et al., 2006). Exposure to $41^{\circ} \mathrm{C}$ for $4 \mathrm{hr}$ at flowering caused irreversible damage and plants became completely sterile (IRRI, 1977), whereas this high temperature $\left(41^{\circ} \mathrm{C}\right)$ had no effect on spikelet fertility at 1 day before or after flowering (Yoshida et al., 1981). 
A temperature increase of $1^{\circ} \mathrm{C}$ shortened the number of days from sowing to heading by $4-5$ days for some genotypes (Nakagawa et al., 2001). There is genotypic variation in spikelet sterility at high temperature in both the sub-species of $O$. sativa, indica and japonica, which can be defined by different temperature thresholds. However, in general, indica is more tolerant to higher temperatures than japonica. Temperatures higher than the optimum induced floret sterility and thus decreased rice yield. Spikelet sterility was greatly increased at temperatures higher than $35^{\circ} \mathrm{C}$. Enhanced $\mathrm{CO}_{2}$ levels may further aggravate this problem possibly because of reduced transpirational cooling (Matsui et al., 1997).

Generally, male reproductive development in rice is known to be more sensitive to heat stress (Wassmann et al., 2009). High-temperature stress during rice flowering led to decreased pollen production and pollen shed. The probable reasons were the inhibition of swelling of pollen grains, indehiscence of anthers and poor release of pollen grains, and thus fewer numbers of pollen grains were available to be intercepted by the stigma.

\section{Plant Responses to Heat Stress}

\subsection{Morpho-anatomical}

Morphological symptoms like including scorching of leaves and twigs, sunburns on leaves, branches and stems, leaf senescence and abscission, shoot and root growth inhibition, fruit discoloration and damage and reduced yield.

\subsection{Anatomical changes}

At the whole plant level, there is a general tendency of reduced cell size, closure of stomata and curtailed water loss, increased stomatal and trichomatous densities, and greater xylem vessels of both root and shoot. In general, it is evident that high temperature considerably affects anatomical structures not only at the tissue and cellular levels but also at the subcellular level. The cumulative effects of all these changes under high temperature stress may result in poor plant growth and productivity.

\subsection{Physiological responses}

\subsubsection{Water relations}

Infield conditions, high temperature stress is frequently associated with reduced water availability. High temperatures seem to cause water loss in plants more during daytime than night time.

\subsubsection{Accumulation of compatible solutes}

Under stress, different plant species may accumulate a variety of osmolytes such as sugars and sugar alcohols (polyols), proline tertiary and quaternary ammonium compounds, and tertiary sulphonium compounds. Accumulation of such solutes may contribute to enhanced stress tolerance of plants.

\subsubsection{Photosynthesis}

Photochemical reactions in thylakoid lamellae and carbon metabolism in the stroma of chloroplast have been suggested as the primary sites of injury at high temperatures. PSII is highly thermo-labile, and its activity is greatly reduced or even partially stopped under high temperatures.

\subsubsection{Assimilate partitioning}

Under low to moderate heat stress, a reduction in source and sink activities may occur leading to severe reductions in growth, economic yield and harvest index

\subsubsection{Cell membrane thermo-stability}

The integrity and functions of biological membranes are sensitive to high temperature, as heat stress alters the tertiary and quaternary structures of membrane proteins.

\subsubsection{Hormonal changes}

Hormonal homeostasis, stability, content, biosynthesis and compartmentalization are altered under heat stress. Abscisic acid (ABA) and ethylene, as stress hormones, are involved in the regulation of many physiological properties by acting as signal molecules.

\subsection{Molecular responses}

\subsubsection{Oxidative stress and antioxidants}

In addition to tissue dehydration, heat stress may induce oxidative stress. For example, generation and reactions of activated oxygen species (AOS) including singlet oxygen, superoxide radical $\left(\mathrm{O}_{2}^{-}\right)$, hydrogen peroxide $\left(\mathrm{H}_{2} \mathrm{O}_{2}\right)$ and hydroxyl radical $\left(\mathrm{OH}^{-}\right)$are symptoms of cellular injury due to high temperature. AOS cause the autocatalytic peroxidation of membrane lipids and pigments thus leading to the loss of membrane semi-permeability and modifying its functions. Decrease in antioxidant activity in stressed tissues results in higher levels of AOS that may contribute to injury. Protection against oxidative stress is an important component in determining the survival of a plant under heat stress.

\subsubsection{Stress proteins}

Most of the stress proteins are soluble in water and therefore contribute to stress tolerance presumably via hydration of cellular structures. Although heat shock proteins (HSPs) are exclusively implicated in heat-stress response, certain other proteins including ubiquitin, cytosolic $\mathrm{Cu} / \mathrm{Zn}-\mathrm{SOD}$ and $\mathrm{Mn}$ POD, whose expressions are stimulated upon heat stress, are also involved. Late embryogenesis abundant (LEA) proteins can prevent aggregation and protect the citrate synthase from desiccating conditions like heat-and drought-stress.

\section{Selection Criteria for Heat Tolerance}

Several parameters have been proposed as selection indexes in breeding for heat tolerance and avoidance in rice. Some important selection indexes used for heat tolerance and avoidance are:

(i) Early morning flowering to escape heat damage and screening for high temperature tolerant lines done at $38^{\circ} \mathrm{C}$ 
while $35^{\circ} \mathrm{C}$ can be used to eliminate heat susceptible materials (Satake and Yoshida, 1978).

(ii) High pollen shedding (i.e., expressed as pollen number on the stigma) (Prasad et al., 2006).

(iii) Pollen production in the anthers and high spikelet fertility for heat tolerance during the reproductive phase (Prasad et al., 2006).

(iv) Grain weight heat susceptibility index [GWHSI = (grain weight at optimum temperature-grain weight at high temperature)/grain weight at optimum temperature $\times 100$ ] to evaluate tolerance of rice to heat stress (Zhu et al., 2005).

(v) Six hour high temperature exposure encompassing the peak anthesis period for the flowering day to reduce the possibility of escape (Jagadish et al., 2008).

(vi) Length of basal dehiscence could be used as morphological marker for selecting high temperature tolerant genotypes (Matsui et al., 2007). They found out that the length of basal dehiscence was highly correlated with the pollination viability under hot conditions. Furthermore, they observed that long basal dehiscence helps the pollen grains to fall from theca into stigma, thereby increasing reliability of pollination under hot and normal environmental conditions.

\section{Conclusion}

Genetic modification of the male reproductive organ should be targeted in future breeding programmes as it is more sensitive to high temperature. More research on the inheritance of tolerance related traits and genotype-by-environment interaction ( $\mathrm{G} \times \mathrm{E})$ is needed. The targeted $\mathrm{G} \times \mathrm{E}$-based findings will not only help to understand the relationship of production environment and genotypic characteristics of rice, but will also help to select better genotypes suitable for particular environments.

\section{References}

Ceccarelli, S., Grando, S., Maatougui, M., Michael, M., Slash, M., Haghparast, R., Rahmanian, M., Taheri, A., Al-yassin, A., Benbelkacem, A., Labdi, M., Mimoun, H., Nachit, M., 2010. Plant breeding and climate changes. Journal of Agricultural Science 148, 627-637.

Crowley, T.J., 2000. Causes of climate change over the past 1000 years. Science 289 (5477), 270-277.

Farrell, T.C., Fox, K.M., Williams, R.L., Fukai, S., 2006. Genotypic variation for cold tolerance during reproductive development in rice: screening with cold air and cold water. Field Crops Research 98, 178-194.

IRRI., 1977. Annual Report. Manila, The Philippines: IRRI.

Jagadish, S.V.K., Craufurd, P.Q., Wheeler, T.R., 2008. Phenotyping parents of mapping populations of rice (Oryza sativa L.) for heat tolerance during anthesis. Crop Science 48, 1140-1146.

Matsui, T., Kobayasi, K., Yoshimoto, M., Hasegawa, T., 2007.
Stability of rice pollination in the field under hot and dry conditions in the Riverina region of New South wales, Australia. Plant Production Science 10, 57-63.

Matsui, T., Namuco, O.S., Ziska, L.H., Horie, T., 1997. Effects of high temperature and $\mathrm{CO}_{2}$ concentration on spikelet sterility in indica rice. Field Crops Research 51, 213-219.

Meehl, G.A., Stocker, T.F., Collins, W.D., Friedlingstein, P., Gaye, A.T., Gregory, J.M., Kitoh, A., Knutti, R., Murphy, J.M., Noda, A., Raper, S.C.B., Watterson, I.G., Weaver, A.J., Zhao, Z.C., 2007. Global Climate Projections. In: Solomon, S., Qin, D., Manning, M., Chen, Z., Marquis, $M$, Averyt, K.B., Tignor, M, Miller, H.L. Climate change 2007: The Physical Science Basis. Contribution of Working Group I to the Fourth Assessment Report of the Intergovernmental Panel on Climate Change Cambridge University Press, Cambridge, United Kingdom and New York, NY, USA.

Nakagawa, H., Takahashi, W., Hasegawa, T., Watanabe, T., Horie, T., 2001. Development of a three-dimensional simulator for rice growth and development. II. Accuracy of a rice phenology model to simulate heading stage and plant age in leaf number. Japanese Journal of Crop Science 70, 125-126.

Peng, S., Huang, J., Sheehy, J.E., 2004. Rice yields decline with higher night temperature from global warming. Proceeding of the National Academy of Sciences 101, 9971-9975.

Prasad, P.V.V., Boote, K.J., Allen, L.H., Sheehy, J.E., Thomas, J.M.G., 2006. Species, ecotype and cultivar differences in spikelet fertility and harvest index of rice in response to high temperature stress. Field Crops Research 95, 398-411.

Satake, T., Yoshida, S., 1978. High temperature- induced sterility in indica rices at flowering. Japanese. Journal of Crop Science 47, 6-17.

Wahid, A., Gelani, S., Ashraf, M., Foolad, M.R., 2007. Heat tolerance in plants: an overview. Environmental and Experimental Botany 6, 199-233.

Wassmann, R., Jagadish, S.V.K., Heuer, S., Ismail, A., Redona, E., Serraj, R., Singh, R.K., Howell, G., Pathak, H., Sumfleth, K., 2009. Climate change affecting rice production; the physiological and agronomic basis for possible adaptation strategies. Advances in Agronomy 101, 59-122.

Yin, X., Kroff, M.J., Goudriann, J., 1996. Differential effects of day and night temperature on development to flowering in rice. Annals of Botany 77, 203-213.

Yoshida, S., 1981. Fundamentals of rice crop science. Los Banos, The Philippines: IRRI.

Zhu, C., Xiao, Y., Wang, C., Jiang, L., Zhai, H., Wan, J., 2005. Mapping QTL for heat-tolerance at grain filling stage in rice. Rice Science 12, 33-38. 